\title{
Investigación acerca de la utilización de los conocimientos científicos y lingüísticos en la interpretación de textos académicos
}

Temporetti, Félix; ${ }^{1}$ Corvalan, Facundo

Recibido: 21/09/2016

Aprobado: 10/10/2016

\section{Resumen}

Este trabajo estudia las estrategias de interpretación de textos argumentativos utilizados por estudiantes universitarios considerando la relevancia que los conocimientos científicos y lingüísticos tienen en la comprensión de los mismos. Estas actividades de interpretación y comprensión están estrechamente relacionadas con la cultura de la educación institucional en la cual los lectores han sido formados. Para el logro de los objetivos perseguidos, fueron observados los procedimientos de lectura e interpretación en una muestra no aleatoria de 32 estudiantes de Psicopedagogía y realizadas posteriormente entrevistas semi-dirigidas. Durante el análisis de las experiencias se evidenció que las anticipaciones sobre el significado de los textos realizada por los estudiantes estaban atravesadas por un conocimiento previo elemental. Dichas anticipaciones revelaron el predominio de una asociación mecánica entre un estímulo lingüístico y un nombre que había sido reforzado por la experiencia educativa. El conocimiento científico estaba asociado a la interpretación del docente. Los grupos ubicaron a los autores en el campo de la Psicología pero sin argumentar con detalles sobre las diferencias y discrepancias que se evidenciaban en los textos utilizados en la situación experimental. Con respecto al conocimiento lingüístico aunque percibieron diferencias de escritura entre un autor y otro fueron incapaces de efectuar una profunda reflexión sobre la intencionalidad comunicativa del autor y su vinculación con la posición teórica o epistemológica adoptada. Tampoco pudieron captar la trama argumentativa y la dimensión dialógica presente en ambos textos.

Palabras clave: Interpretación, Conocimientos Científicos, Aptitudes Académicas.

\footnotetext{
${ }^{1}$ Universidad Nacional de Rosario. Instituto Universitario del Gran Rosario. Rosario - Santa Fe - Argentina Pasaje Alfonsina Storni 777, P.11 Código Postal 2000 - Teléfono 0341-155 820034 .email: felixtemporetti@ yahoo.com.ar
} 
Temporetti, Félix y otro | Investigación acerca de la utilización de los conocimientos científicos...

\section{Summary}

This paper studies the interpretation strategies of argumentative texts used by university students considering the relevance of scientific and linguistic knowledge have in their understanding. Interpretation and understanding are closely related to the culture of institutional education where readers have been trained.

Strategies of reading and interpretation, subsequently complemented with semi-directed interviews were observed and applied, respectively, in a non random sample of 16 students of Psychopedagogy students to achieve the pursued objectives.

During the analysis of experience it resulted evident that the anticipations performed by the students on the meaning of texts were crossed by an elementary foreknowledge. Such anticipations revealed the predominance of a mechanical association between a linguistic stimulus and a name that had been reinforced by the educational experience.

Scientific knowledge was associated with teacher's interpretation. The groups placed the authors in the field of Psychology without arguing in detail about the evident differences and discrepancies appearing in the employed texts. Regarding the linguistic knowledge though the students detected differences between an author and another they were not able to carry out a deep reflection on the author's communicative intention and his links with the theoretical or epistemological position adopted. Likewise, they were unable to grasp the argumentative plot and the dialogic dimension present in both texts.

Keywords: Interpretation, Scientific Knowledge, Academic Skills. 